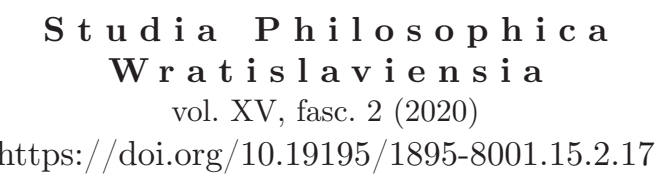

MAREK BŁASZCZYK

ORCID: 0000-0001-5518-0115

Uniwersytet Mikołaja Kopernika w Toruniu

\title{
O absurdzie w twórczości Alberta Camusa
}

Maciej Kałuża, Elementy filozofii absurdu w dramaturgii Alberta Camusa, Wydawnictwo LIBRON, Kraków 2016, ss. 278.

Monografia Macieja Kałuży, podejmująca problematykę absurdu w myśli Alberta Camusa, zajmuje szczególne miejsce pośród dotychczasowych polskojęzycznych publikacji poświęconych temu filozofowi. Nie tyle stanowi ona kolejne opracowanie jego filozoficznego dorobku, ile uzupełnia owe prace o stosunkowo rzadko eksponowaną analizę jego twórczości dramatycznej. Książkę Kałuży można więc uznać za ważny krok w stronę systematyzacji wymykającej się naukowemu ujęciu refleksji francuskiego noblisty.

Głównym celem monografii Kałuży jest ,prześledzenie rozwoju myśli Alberta Camusa, skupionej na refleksji nad zagadnieniem absurdu"1. Swoje zamierzenie Kałuża formułuje także następująco: „odtworzyć filozoficzne znaczenie i konsekwencje absurdu we wczesnej myśli Camusa, rozwijającej się paralelnie w eseistyce filozoficznej, dramaturgii i literaturze"2. Trzeba tutaj od razu zaznaczyć, że choć omawiana książka jest wartościowym, zasługującym na uwagę przedsięwzięciem naukowym, to jednak pewien niedosyt może budzić marginalne potraktowanie zagadnienia absurdu w literackich dziełach Camusa. Tym bardziej że — jak powiada sam autor - jego analiza „obejmuje zarówno teksty dramatyczne, literackie, jak i filozoficzne"3. Osobliwe wydaje się również, że tylko jedna trzecia pracy Kałuży poświęcona jest twórczości dramatycznej Camusa, co podaje w wątpliwość zasadność (trafność) jej tytułu. Wątpliwości rodzi także konstrukcja spisu treści wstęp, zakończenie oraz bibliografia są bowiem numerowane, podobnie jak rozdzia-

\footnotetext{
${ }^{1}$ M. Kałuża, Elementy filozofii absurdu w dramaturgii Alberta Camusa, Kraków 2016, s. 15.

${ }^{2}$ Ibidem.

${ }^{3}$ Ibidem, s. 17.
} 
ły publikacji. Taki układ spisu treści sprawia wrażenie, a nawet mylnie sugeruje, że praca ta składa się z sześciu kolejno numerowanych rozdziałów, w tym wstępu, zakończenia i bibliografii. Zaletą monografii jest natomiast naświetlenie kontekstu filozoficznej refleksji nad absurdem (genezy absurdu filozoficznego), a zwłaszcza wskazanie na prekursorów myśli Camusa ${ }^{4}$.

Kałuża słusznie zauważa, że znaczaccy wpływ na twórczość Camusa mieli Blaise Pascal, Søren Kierkegaard i Friedrich Nietzsche. Egzystencjalny namysł nad absurdem — podkreśla autor — bierze swój początek z Pascalowskich rozważań nad sytuacją człowieka w świecie:

ostatecznie bowiem czymże jest człowiek w przyrodzie? Nicością wobec nieskończoności, wszystkim wobec nicości, pośrodkiem między niczym a wszystkim. Jest nieskończenie oddalony od rozumienia ostateczności; cel rzeczy i ich początki są dlań na zawsze ukryte w nieprzeniknionej tajemnicy; równie niezdolny jest dojrzeć nicości, z której go wyrwano, jak nieskończoności, w której go pogrążono ${ }^{5}$.

Wyłuszczenie owego napięcia między pragnącym nieskończoności człowiekiem a otaczającym go światem doczesnym czyni niewątpliwe Pascala pionierem współczesnej filozofii egzystencjalnej. Największym filozoficznym osiągnięciem Pascala jest właśnie uświadomienie jednostce jej własnej kondycji — kruchej, marnej, znikomej w obliczu potęgi wszechświata, ale i nieustannie transcendującej myślą swe aktualne położenie w świecie. Można zatem powiedzieć, że rozważania Pascala w pewnym sensie zapowiadają Camusowską filozofię absurdu. Autor Mitu Syzyfa nie tylko cenił sobie spostrzeżenia francuskiego myśliciela, lecz także wprost do nich nawiązywał, interpretując tragizm ludzkiej egzystencji w kontekście doświadczenia absurdu. Filozofia Camusa, w przeciwieństwie do refleksji Pascala, nie jest jednak mocno zorientowana religijnie ${ }^{6}$.

Camus inspirował się również filozofią Kierkegaarda, powszechnie uważanego za ojca dwudziestowiecznego egzystencjalizmu. Kałuża podkreśla, że „Camusowski absurd jest silnie związany z Kierkegaardowskim rozumieniem paradoksu"”. Pokrewieństwo absurdu i paradoksu nie sprowadza się tu bynajmniej jedynie do tego, że są to swoiste dla opisu ludzkiego sposobu bycia kategorie egzystencjalne. Łączy je też to, że stanowią one wyraźną cezurę dla poznania naukowego (racjonalnego, spekulatywnego): „paradoks i absurd wyznaczają granicę dla rozumu”. A więc Camus nie tylko podziela Kierkegaardowską kontestację apriorycznych twierdzeń o rzeczywistości i ludzkim życiu, lecz także jego krytykę filozofii systemowej (zwłaszcza heglizmu), dążącej do obiektywizacji jednostkowego doświadczenia egzystencjalnego. Warto nadmienić, że przekroczenie poczucia absurdu możliwe jest według Kierkegaarda wyłącznie poprzez zwrot ku religijnemu stadium egzystencji — przez przyjęcie i zaakceptowanie paradoksu wiary ${ }^{9}$. Dla Camusa natomiast niezgoda na absurd wiąże się z przyjęciem postawy zbuntowanej: ,absurd ma sens tylko o tyle,

\footnotetext{
${ }^{4}$ Por. ibidem, s. 31-55.

${ }^{5}$ B. Pascal, Myśli, tłum. T. Żeleński (Boy), Warszawa 2002, s. 53.

${ }^{6}$ Por. A. Camus, Notatniki 1935-1959, tłum. J. Guze, Warszawa 1994, s. 248.

7 M. Kałuża, Elementy filozofii..., s. 12.

8 Ibidem, s. 41.

${ }^{9}$ S. Kierkegaard, Bojaźń i drżenie. Choroba na śmierć, tłum. J. Iwaszkiewicz, Warszawa 1982.
} 
o ile się na niego zgadzamy"10. Dodajmy, że Avi Sagi — na co zwraca również uwagę Kałuża — określa Kierkegaarda i Camusa mianem personal thinkers, „myślicieli subiektywnych"11, „wychodzacych od tego, co osobiste"12. Jak celnie pisze krakowski badacz: ,w obydwu przypadkach manifestuje się [...] obecność myśliciela w refleksji, osobiste zaangażowanie w odkrywanie prawdy"13.

Camus interesował się wreszcie filozofia Nietzschego ${ }^{14}$. Co ciekawe, odwoływało się do niej wielu znanych współczesnych filozofów, jak choćby Lew Szestow ${ }^{15}$, Karl Jaspers $^{16}$, Martin Heidegger ${ }^{17}$, Gilles Deleuze ${ }^{18}$, Rüdiger Safranski ${ }^{19}$ czy Gianni Vattimo $^{20}$. Kałuża dostrzega tutaj pewne związki między Camusowskim pojęciem absurdu a Nietzscheańskim rozumieniem nihilizmu ${ }^{21}$. Podkreśla, że tak jak dla Nietzschego punktem wyjścia jest namysł nad nihilizmem ${ }^{22}$, tak dla Camusa namysł nad absurdem ${ }^{23}$. Jednak zarówno nihilizm u Nietzschego, jak i absurd u Camusa nie stanowią konkluzji ich filozoficznej refleksji. Autor Wiedzy radosnej, ogłaszajacc ,śmierć Boga”, postuluje przewartościowanie utrwalonych przez wieki i obowiązujących w zachodniej kulturze wartości ${ }^{24}$. Ostrze swej krytyki kieruje przede wszystkim w stronę moralności chrześcijańskiej, która istotnie - jego zdaniem - przyczyniła się do powstania nihilizmu ${ }^{25}$. Camus, nawiązując do rozpoznań Nietzschego, mówi natomiast o „wrażliwości absurdalnej, tu i ówdzie spotykanej w naszym wieku"26. Zauważmy, że francuskiego intelektualistę, podobnie jak niemieckiego filozofa, interesuje tutaj pytanie o sens życia, a dokładniej: pytanie o to, jak żyć w świecie pozbawionym Boga, a co za tym idzie — wartości uniwersalnych, ponadhistorycznych, nadnaturalnych. Camus jednak nie do końca podziela stanowisko swego poprzednika - w przeciwieństwie bowiem do niego nie porzuca „tęsknoty za transcendencją". Kałuża wspomina o tym fakcie ${ }^{27}$, powołujacc się na ustalenia Sagiego ${ }^{28}$. Warto dodać, uzupełniając wywód krakowskiego badacza, że

\footnotetext{
10 A. Camus, Mit Syzyfa, [w:] idem, Eseje, tłum. J. Guze, Warszawa 1971, s. 115.

11 Por. A. Sagi, Albert Camus and the Philosophy of the Absurd, Amsterdam-New York 2002, s. 26.

${ }^{12}$ M. Kałuża, Elementy filozofii..., s. 43.

13 Ibidem.

14 A. Camus, Człowiek zbuntowany, [w:] idem, Eseje, s. 319-332.

${ }^{15}$ L. Szestow, Dostojewski i Nietzsche. Filozofia tragedii, tłum. C. Wodziński, Warszawa 1987.

${ }^{16}$ K. Jaspers, Nietzsche. Wprowadzenie do rozumienia jego filozofii, tłum. D. Stroińska, Warszawa 1997; idem, Rozum i egzystencja. Nietzsche a chrześcijaństwo, tłum. C. Piecuch, Warszawa 1991.

17 M. Heidegger, Nietzsche, t. 1-2, tłum. A. Gniazdowski et al., Warszawa 1998-1999; idem, Powiedzenie Nietzschego „Bóg umarł”, tłum. J. Gierasimiuk, [w:] idem, Drogi lasu, tłum. J. Gierasimiuk et al., Warszawa 1997, s. 171-216.

18 G. Deleuze, Nietzsche i filozofia, tłum. B. Banasiak, Warszawa 1998.

${ }^{19}$ R. Safranski, Nietzsche. Biografia myśli, tłum. D. Stroińska, Warszawa 2003.

${ }^{20}$ G. Vattimo, Nietzsche. Eine Einführung, Stuttgart 1992.

${ }^{21}$ Por. M. Kałuża, Elementy filozofii..., s. 45-50.

${ }^{22}$ Por. W. Kaufmann, Nietzsche. Philosopher, Psychologist, Antichrist, Princeton 1974, s. 96 n.

${ }^{23}$ Por. A. Camus, Mit Syzyfa, s. 90: „trzeba jednak podkreślić, że absurd, traktowany dotychczas jako konkluzja, rozpatrywany jest tutaj jako punkt wyjścia".

${ }^{24}$ Por. F. Nietzsche, Wiedza radosna, tłum. L. Staff, Kraków 2003.

25 Por. F. Nietzsche, Wola mocy, tłum. S. Frycz, K. Drzewiecki, Kraków 2003.

26 A. Camus, Mit Syzyfa, s. 90.

27 Por. M. Kałuża, Elementy filozofii..., s. 49.

${ }^{28}$ Por. A. Sagi, Albert Camus and the Philosophy of the Absurd, s. 84.
} 
autor Mitu Syzyfa nie tylko konstatował, iż dzięki postawie zbuntowanej możliwe zdaje się wypracowanie zorientowanej na pryncypia humanistyczne (ogólnoludzkie) „wspólnej moralności” („buntuję się, więc jesteśmy”29), lecz także głęboko szanował i wysoko cenił wartości chrześcijańskie ${ }^{30}$. Trudno więc uznać jego ateizm za doktrynalny i programowo konsekwentny. Co więcej — kwestię tę Kałuża pomija - niektórzy interpretatorzy twórczości Camusa doszukują się w niej nawet wątków religijnych i metafizycznych ${ }^{31}$.

Omawiana książka jest ciekawą próbą odczytania dzieł francuskiego filozofa przez pryzmat kluczowej dla jego wczesnej twórczości kategorii absurdu. Kałuża proponuje bowiem wszystkie teksty składające się na Camusowski „tryptyk o absurdzie" interpretować komplementarnie jako wzajemnie uzupełniające się i przenikające całości:

wszystkie trzy dzieła tryptyku mają na siebie wzajemny wpływ, uzupełniają się, dopełniają obrazu, który, choć w ostatecznym rozrachunku nie jest jednoznaczny, zyskuje pełniejszy wymiar dopiero po założeniu, że w ich przypadku lepiej jest łączyć, niż dzielićc ${ }^{32}$.

Godny pochwały jest też już sam wybór podjętej przez Kałużę problematyki. Nie tylko bowiem nie podąża on za różnymi zdominowanymi współczesną humanistykę modami, lecz także nie boi się opracowania „na nowo” zagadnienia, które może dziś uchodzić za anachroniczne i przebrzmiałe. Przede wszystkim jednak należy docenić to, że autor eksponuje w swej publikacji — dość rzadko podnoszony w literaturze przedmiotu — namysł nad absurdem w wybranych utworach dramatycznych Camusa (Kaligula, Nieporozumienie). Monografia Kałuży wyraźnie świadczy również o tym, że myśl egzystencjalna Camusa nadal inspiruje do przemyśleń, skłaniając do żywej akademickiej debaty.

\section{Bibliografia}

Camus A., Człowiek zbuntowany, [w:] idem, Eseje, tłum. J. Guze, Warszawa 1971.

Camus A., Mit Syzyfa, [w:] idem, Eseje, tłum. J. Guze, Warszawa 1971.

Camus A., Notatniki 1935-1959, tłum. J. Guze, Warszawa 1994.

Camus A., Pozostańcie chrześcijanami, tłum. A. Koprowska, M. Rapacki, „Gazeta Wyborcza" 261 (2003).

Deleuze G., Nietzsche i filozofia, tłum. B. Banasiak, Warszawa 1998.

Grzegorczyk A., Filozofia Nieoczekiwanego, Poznań 2002.

Grzegorczyk A., Kochanek prawdy. Rzecz o twórczości Alberta Camusa, Katowice 1999. Heidegger M., Nietzsche, t. 1-2, tłum. A. Gniazdowski et al., Warszawa 1998-1999.

${ }^{29}$ A. Camus, Człowiek zbuntowany, s. 274.

${ }^{30}$ Por. A. Camus, Pozostańcie chrześcijanami, tłum. A. Koprowska, M. Rapacki, „Gazeta Wyborcza" 261 (2003), s. 28.

${ }^{31}$ Por. A. Grzegorczyk, Kochanek prawdy. Rzecz o twórczości Alberta Camusa, Katowice 1999, s. 63; T. Judt, Brzemię odpowiedzialności. Blum, Camus, Aron i francuski wiek dwudziesty, tłum. M. Filipczuk, Warszawa 2013, s. 125-126; H. Lottman, Albert Camus. Biografia, tłum. I. Szymańska, Warszawa 1996, s. 338; A. Grzegorczyk, Filozofia Nieoczekiwanego, Poznań 2002, s. 109.

${ }^{32}$ M. Kałuża, Elementy filozofii..., s. 19. 
Heidegger M., Powiedzenie Nietzschego „Bóg umart”, tłum. J. Gierasimiuk, [w:] idem, Drogi lasu, tłum. J. Gierasimiuk et al., Warszawa 1997.

Jaspers K., Nietzsche. Wprowadzenie do rozumienia jego filozofii, tłum. D. Stroińska, Warszawa 1997.

Jaspers K., Rozum i egzystencja. Nietzsche a chrześcijaństwo, tłum. C. Piecuch, Warszawa 1991.

Judt T., Brzemię odpowiedzialności. Blum, Camus, Aron i francuski wiek dwudziesty, tłum. M. Filipczuk, Warszawa 2013.

Kałuża M., Elementy filozofii absurdu w dramaturgii Alberta Camusa, Kraków 2016.

Kaufmann W., Nietzsche. Philosopher, Psychologist, Antichrist, Princeton 1974.

Kierkegaard S., Bojaźn i drżenie. Choroba na śmierć, tłum. J. Iwaszkiewicz, Warszawa 1982.

Lottman H., Albert Camus. Biografia, tłum. I. Szymańska, Warszawa 1996.

Nietzsche F., Wiedza radosna, tłum. L. Staff, Kraków 2003.

Nietzsche F., Wola mocy, tłum. S. Frycz, K. Drzewiecki, Kraków 2003.

Pascal B., Myśli, tłum. T. Żeleński (Boy), Warszawa 2002.

Safranski R., Nietzsche. Biografia myśli, przeł. D. Stroińska, Warszawa 2003.

Sagi A., Albert Camus and the Philosophy of the Absurd, Amsterdam-New York 2002.

Szestow L., Dostojewski i Nietzsche. Filozofia tragedii, tłum. C. Wodziński, Warszawa 1987.

Vattimo G., Nietzsche. Eine Einführung, Stuttgart 1992. 